\title{
Rootstock screening for greenhouse tomato production under a coconut coir cultivation system
}

\author{
Lulu Sun ${ }^{1}$, Wenchao Zhao ${ }^{1}$, Man Jiang ${ }^{1}$, Rui Yang ${ }^{1}$, Xuebing Sun ${ }^{1}$, Jianli Wang ${ }^{1}$, and Shaohui Wang ${ }^{1 *}$ \\ ${ }^{1}$ Beijing University of Agriculture, Plant Science and Technology College, Beijing Key Laboratory for Agricultural Applications and \\ New Techniques, 102206, Beijing, China. *Corresponding author (wangshaohui@ bua.edu.cn).
}

Received: 9 November 2020; Accepted: 29 January 2021; doi:10.4067/S0718-58392021000200202

\begin{abstract}
Grafting is an important means to overcome the obstacles of continuous cropping of solanaceous vegetables. The objective of this subject was to evaluate the performance of different rootstocks in grafted tomato (Solanum lycopersicum L.) under coconut coir cultivation. This research was carried out on a scion 'Ruifen 882' grafted onto four rootstocks ('Guangzhen 1', 'Zhenai 1', 'Ganzhen 1', and 'Guozhen 1') in comparison with non-grafted and self-grafted 'Ruifen 882 ' plants. The experiment was conducted in a greenhouse environment and adopted the casing grafting method with three replicates; 20 plants per replicate were employed in a randomized block design. The following variables were analyzed: graft survival rate, growth parameters (plant height, stem diameter, fresh and dry weight of above-ground part and under-ground part, root-shoot ratio and strong seedling index), physiological characteristics (chlorophyll and mineral element contents), fruit yield, and fruit quality (hardness, soluble solid, soluble sugar, titratable acid, vitamin C and lycopene). The results of growth monitoring indicated that grafting could improve the growth and development of tomato plants at the seedling stage and 'Ruifen $882^{\prime} /{ }^{\prime}$ Guozhen 1' (R/GUO) had high grafting survival rate of nearly $98 \%$, which is close to the self-grafted plants. Physiological analysis showed that R/GUO and 'Ruifen 882'/'Zhenai 1' (R/ ZA) significantly increased the chlorophyll content and absorption of $\mathrm{K}, \mathrm{Ca}, \mathrm{Mg}, \mathrm{Fe}, \mathrm{Na}, \mathrm{Mn}$ and $\mathrm{Cu}$. On fruit yield, grafts 'Ruifen 882 '/“Ganzhen 1' (R/GAN) and R/GUO had better performance. Comprehensive analysis showed that the best results for tomato scion growth, development, fruit quality and yield were observed with the graft combination R/GUO.
\end{abstract}

Key words: Coconut coir, greenhouse, production, rootstocks, Solanum lycopersicum, tomato.

\section{INTRODUCTION}

Tomato (Solanum lycopersicum L.) is one of the most popular vegetables worldwide (Mauromicale et al., 2011; HernándezLeal et al., 2019). Grafting is an important horticultural technology to overcome the obstacles of continuous cropping, improve the tolerance of plants to poor water quality or drought, alleviate a variety of soil-borne diseases and insect pests, increase crop yield, and improve fruit quality under greenhouse tomato production (Savvas et al., 2012; Fallik and Ilic, 2014).

Rootstock is the most important factor in the grafting process that influences the graft survival rate and growth indexes, physiological parameters, hormone contents, flowering order and molecular variation (Ceballos and Rioja, 2019). Selecting suitable rootstock/scion combinations can ensure high-yield and high-quality fruits (Aloni et al., 2010; Flores et al., 2010; Rouphael et al., 2010; Nguyen and Yen, 2018).

In recent years, soilless culture techniques have been frequently used in solanaceous vegetable cultivation. Coconut coir is widely used in soilless culture because it is rich in fiber, has good water and fertilizer retention, and has excellent air permeability, making it suitable for plant growth and development (Oliveira et al., 2009; Berruti and Scariot, 2012; Xiong et al., 2017; Wang et al., 2020). For example, in production of acidophilic plants, such as camellia and rhododendron, peat can be partially substituted by coconut fibers at a rate up to $50 \%$ without adverse effects on plant health and appearance but is more economic and environment-friendly than the use of peat alone (Berruti and Scariot, 2012). A previous study 
indicated that coconut coir was a potential substrate that could be widely used in tomato production (Xiong et al., 2017). Coconut fiber powder can affect the absorption of nutrients in the production of eggplant seedlings (Oliveira et al., 2009). However, fewer studies on tomato rootstock suitable for coconut coir cultivation have been reported.

Thus, in this experiment, four tomato rootstocks were used as test materials, and the commercial 'Ruifen 882' was used as a scion for casing grafting. This study synthetically analyzed the growth, development, fruit yield and quality of tomato of different scion/rootstock combinations under greenhouse soilless culture (coconut coir cultivation system) with the aim of screening suitable tomato rootstocks and providing a theoretical basis for the screening of grafted tomato rootstocks under coconut coir cultivation.

\section{MATERIALS AND METHODS}

\section{Plant materials and growth conditions}

The trial was conducted in a greenhouse at the Grand View Garden in Xiaotangshan, Changping District, Beijing, during 2018. A commercial cultivar of tomato (Solanum lycopersicum L.), 'Ruifen 882' (R), purchased from Rijk Zwaan, De Lier, Netherlands, was used as a scion in this experiment and was either self-grafted or grafted onto four different rootstocks: 'Guangzhen 1' (GUANG), 'Zhenai 1' (ZA), 'Ganzhen 1' (GAN), and 'Guozhen 1' (GUO), which were provided by the Beijing Academy of Agriculture and Forestry Sciences (BAAFS), Beijing Vegetable Research Center (BVRC) and Beijing Agricultural Technology Extension Station. Seeds of the scion and rootstocks were sown in seeding dishes filled with nursery substrates that were artificially mixed with a proportion of peat:vermiculite in a 1:1 ratio. The sowing date of the rootstocks was 14 February, 1 wk earlier than that of the scion, and grafting was conducted using the casing grafting method (Lee et al., 2010; Rouphael et al., 2010) with slight modification at the seedling stage (three to four true leaves) on 24 March. On 16 April, $32 \mathrm{~d}$ after grafting, seedlings were transplanted to the greenhouse with $35 \mathrm{~cm}$ plant spacing and $1 \mathrm{~m}$ line spacing, and coconut coir as cultivation substrate. The experiment was a completely randomized block design with three replicates per graft combination and each replicate consisted of 20 plants. Four scion/rootstock combinations, 'Ruifen $882^{\prime} /{ }^{\prime}$ Guozhen 1' (R/GUO), 'Ruifen 882'/“Ganzhen 1' (R/GAN), 'Ruifen 882'/“Guangzhen 1' (R/GUANG), 'Ruifen 882'/“Zhenai 1' (R/ZA) and two control combinations 'Ruifen 882' non-grafted (R) and self-grafted (R/R) seedlings are shown in Table 1 .

Two different nutrient solutions were supplied at the initial stage (before 2-spike inflorescence) and the later stage (5 spike to 10 spike inflorescences) after transplanting (Table 2). The electrical conductivity (EC) and the $\mathrm{pH}$ value were maintained at $2.6-2.8 \mathrm{mS} \mathrm{cm}^{-1}$ and 6.0-6.3, respectively. The daily irrigation timing was $5 \mathrm{~min} \mathrm{~h}^{-1}$ and $10 \mathrm{~h} \mathrm{~d}^{-1}$ (07:00-16:00 h), and the solution supply was $1 \mathrm{~L} \mathrm{plant}^{-1} \mathrm{~d}^{-1}$.

Table 1. Different scion/rootstock combinations used in this study and their abbreviations.

\begin{tabular}{ll}
\hline Scion/Rootstock & Abbreviation \\
\hline 'Ruifen 882 ' & $\mathrm{R}$ \\
'Ruifen 882 '/'Ruifen 882 ' & $\mathrm{R} / \mathrm{R}$ \\
'Ruifen 882 '/'Guozhen 1' & $\mathrm{R} / \mathrm{GUO}$ \\
'Ruifen 882 '/'Ganzhen 1' & $\mathrm{R} / \mathrm{GAN}$ \\
'Ruifen 882 '/'Guangzhen 1' & $\mathrm{R} / \mathrm{GUANG}$ \\
'Ruifen 882 '/'Zhenai 1' & $\mathrm{R} / \mathrm{ZA}$ \\
\hline
\end{tabular}

Table 2. Nutrient solution formula for transplanting seedlings.

\begin{tabular}{|c|c|c|}
\hline $\begin{array}{l}\text { Nutrient solution } \\
\text { composition }\end{array}$ & $\begin{array}{l}\text { Before } 2 \text { spike } \\
\text { inflorescence }\end{array}$ & $\begin{array}{l}5 \text { to } 10 \text { spike } \\
\text { inflorescence }\end{array}$ \\
\hline & 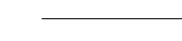 & \\
\hline $\mathrm{Ca}\left(\mathrm{NO}_{3}\right)_{2} \cdot 4 \mathrm{H}_{2} \mathrm{O}$ & 708.00 & 856.68 \\
\hline $\mathrm{KNO}_{3}$ & 487.00 & 655.49 \\
\hline $\mathrm{KH}_{2} \mathrm{PO}_{4}$ & 219.00 & 170.00 \\
\hline$\left(\mathrm{NH}_{4}\right)_{2} \mathrm{SO}_{4}$ & 66.00 & 82.50 \\
\hline $\mathrm{MgSO}_{4} \cdot 7 \mathrm{H}_{2} \mathrm{O}$ & 512.00 & 339.48 \\
\hline $\mathrm{K}_{2} \mathrm{SO}_{4}$ & - & 240.12 \\
\hline EDTA-FeNa $3 \mathrm{H}_{2} \mathrm{O}$ & 10.52 & 6.31 \\
\hline $\mathrm{MnSO}_{4} \cdot \mathrm{H}_{2} \mathrm{O}$ & 2.45 & 1.69 \\
\hline $\mathrm{ZnSO}_{4} \cdot 7 \mathrm{H}_{2} \mathrm{O}$ & 1.32 & 1.43 \\
\hline $\mathrm{Na}_{2} \mathrm{~B}_{4} \mathrm{O}_{7} \cdot 10 \mathrm{H}_{2} \mathrm{O}$ & 12.19 & 2.85 \\
\hline $\mathrm{CuSO}_{4} \cdot 5 \mathrm{H}_{2} \mathrm{O}$ & 0.39 & 0.18 \\
\hline $\mathrm{Na}_{2} \mathrm{MoO}_{4} \cdot 2 \mathrm{H}_{2} \mathrm{O}$ & 0.12 & 0.12 \\
\hline
\end{tabular}




\section{Grafting}

The casing grafting method was performed in this study, as previously described and with slight modifications (Lee et al., 2010). When the scion had three true leaves and the rootstocks had four true leaves, apparently healthy seedlings with consistent growth vigor were selected for grafting.

One day before grafting, the seedlings were sprinkled with water to keep wet, and then transferred to a plastic tunnel covered with two layers of plastic film and two layers of shade nets. When grafting, the hypocotyl was cut at an angle of $30^{\circ}$ and a distance of $2-3 \mathrm{~cm}$ above the cotyledons of the rootstock, then a casing was placed slightly higher than the cut of the rootstock. The scion hypocotyl was cut in the opposite direction of the rootstock at an angle of $30^{\circ}$ and a distance of 0.5-1.0 cm under the first true leaf. The cut surfaces of the scion and rootstock were aligned and fixed within the casing.

Non-grafted and grafted plants were kept for 1 wk under controlled conditions $\left(28^{\circ} \mathrm{C}\right.$ with $\left.95 \% \mathrm{RH}\right)$. The plastic tunnel was sealed for the first $3 \mathrm{~d}$ and then ventilated for 10,20 and $30 \mathrm{~min}$ on the $4^{\text {th }}, 5^{\text {th }}, 6^{\text {th }}$ and $7^{\text {th }}$ days, respectively. The plants were covered with shading net for $5 \mathrm{~d}$ to reduce leaf transpiration after grafting, and then the light duration was gradually increased. Then, the plants were transplanted to coconut coir cultivation substrate in a greenhouse, and the temperature was controlled at $20-26^{\circ} \mathrm{C}$ during the day and $12-15^{\circ} \mathrm{C}$ during the night.

\section{Growth monitoring}

The grafting survival rate was determined 2 wk after grafting, and biometrical parameters (plant height, stem diameter, fresh and dry weight of above-ground part and under-ground part) were evaluated $20 \mathrm{~d}$ after transplanting.

Grafting survival rate $(\%)=($ Number of grafted live plants/Total number of grafted plants $) \times 100 \%$

The strong seedling index and the root/shoot ratio were calculated as follows (Chang et al., 2010; Zhao et al., 2018):

Strong seedling index $=($ Stem diameter $/$ Plant height $) \times$ Whole plant dry weight $\times 100 \%$

Root-shoot ratio $=$ Under-ground dry weight/Above-ground dry weight

\section{Physiological analysis}

Physiological parameters (chlorophyll content, mineral element content) were measured $30 \mathrm{~d}$ after transplanting. The chlorophyll content was measured by ethanol extraction colorimetry (Wang et al., 2017), and the mineral element content of the plant was measured by the dry ashing method (Xiong et al., 2017).

\section{Fruit yield and quality assessment}

Fruit yield per plant and fruit weight were calculated at $85 \mathrm{~d}$ after transplanting. Fruit quality parameters (hardness, soluble solid, soluble sugar, titratable acidity, vitamin C and lycopene) were recorded. Hardness was measured by a GY-1 hardness tester; the soluble solid content was determined by a digital hand-held Brix meter (PAL-1, ATAGO, Tokyo, Japan); soluble sugar content was determined by the fluorenone colorimetric method (Krumbein et al., 2004); titratable acidity was determined by acid-base titration (Auerswald et al., 1996); vitamin C content was determined by 2,6-dichlorophenol indophenol titration (Andrjushchenko et al., 1978); and lycopene content was measured by toluene extraction colorimetry (Krumbein et al., 2006).

\section{Statistical analysis}

Statistical analyses and mapping were performed using SPSS (TIBCO Software, Palo Alto, California, USA) and SigmaPlot 12.5 software (Systat Software, San Jose, California, USA), respectively. Data were analyzed according to ANOVA and means were separated by Duncan's multiple range test.

\section{RESULTS}

\section{Grafting success and growth monitoring}

The grafting survival rate is one of the important parameters for the assessment of the feasibility of grafting success. The data in Table 3 show that the self-grafted plants had the highest grafting survival rate of $98.55 \%$, followed by that of R/GUO, which was $97.93 \%$. Moreover, other graft combinations also had more than $90 \%$ survival rates, indicating good affinity. 
Table 3. Comparison of survival rates under different graft combinations.

\begin{tabular}{lccc}
\hline Scion/Rootstock & $\begin{array}{c}\text { Number of living } \\
\text { plants }\end{array}$ & $\begin{array}{c}\text { Total number of } \\
\text { plants }\end{array}$ & $\begin{array}{c}\text { Survival rate } \\
(\%)\end{array}$ \\
\hline R/R & 68 & 69 & 98.55 \\
R/GAN & 163 & 173 & 94.22 \\
R/ZA & 136 & 142 & 95.77 \\
R/GUO & 189 & 193 & 97.93 \\
R/GUANG & 188 & 206 & 91.26 \\
\hline
\end{tabular}

R/R: 'Ruifen 882'/'Ruifen 882'; R/GAN: 'Ruifen 882'/'Ganzhen 1'; R/ZA: 'Ruifen 882'/'Zhenai 1'; R/GUO: 'Ruifen 882'/‘Guozhen 1'; R/GUANG: 'Ruifen 882'/‘Guangzhen 1'.

Biometrical parameters, such as plant height, stem diameter, and the fresh and dry weights of aboveground and underground part, reflect the growth vigor of plants, and grafting is thought to influence them. The plants grafted onto rootstocks showed significantly greater vegetative growth than the non-grafted and self-grafted plants. The plant heights of graft combinations were significantly lower than those of controls, but the stem diameter, fresh and dry weight of under-ground part, dry weight of above-ground part, dry weight of whole plant, root-shoot ratio, and strong seedling index were all significantly higher for graft combination than for control combinations; only the fresh weight of above-ground part was not consistent with these other parameters (Table 4). Among the four grafted combinations, R/ZA had the highest plant height, followed by R/GAN, R/GUO and R/GUANG. R/GAN had the highest stem diameter, followed by R/ZA. The dry weight of above-ground part and the fresh and dry weight of under-ground part of R/ZA were higher than those of the other graft combinations, and R/GAN had a higher fresh weight of above-ground part than the other graft combinations. Therefore, R/ZA had the highest dry weight of the whole plant (above-ground and under-ground part), followed by R/GAN. The root-shoot ratio was the proportion of under-ground dry weight to above-ground dry weight, and R/GUANG had the highest root-shoot ratio. The strong seedling index also reflects plant growth, and R/GAN had the highest strong seedling index value in this study, followed by R/ZA. The above results indicated that grafting improved the growth and development of tomato plants at the seedling stage.

\section{Chlorophyll and mineral nutrient absorption analyses}

The chlorophyll content and mineral nutrient absorption are common indicators for evaluating plant growth and nutritional status. These parameters of different graft combinations were measured $30 \mathrm{~d}$ after transplanting. The results indicated that different rootstocks have inconsistent effects on the chlorophyll content of grafted plants. R/GUO, R/ZA and R/GUANG showed a significantly increased chlorophyll content compared with those of $\mathrm{R}$ and R/R, although R/GAN showed a reduced chlorophyll content (Figure 1).

Grafting also influenced the absorption of mineral nutrients. The data in Table 5 show that the absorption of most mineral nutrients of grafted seedlings was decreased compared with that of non-grafted seedlings except for $\mathrm{K}$ and $\mathrm{Zn}$, and there was no obviously tendency for self-grafted plants. Among the four graft combinations, R/GUO had the highest absorption of $\mathrm{K}, \mathrm{Ca}, \mathrm{Mg}, \mathrm{Fe}, \mathrm{Na}, \mathrm{Mn}$ and $\mathrm{Cu}$, and relatively lower absorption of $\mathrm{P}$ and $\mathrm{Zn}$. R/ZA, R/GAN and R/GUNAG absorbed the least mineral nutrients.

Table 4. Monitoring of biometrical parameters under different grafting combinations.

\begin{tabular}{|c|c|c|c|c|c|c|c|c|c|}
\hline \multirow[b]{2}{*}{ Scion/Rootstock } & \multicolumn{2}{|c|}{$\begin{array}{l}\text { Above-ground } \\
\text { part }\end{array}$} & \multicolumn{2}{|c|}{$\begin{array}{l}\text { Under-ground } \\
\text { part }\end{array}$} & \multirow[b]{2}{*}{$\begin{array}{l}\text { Dry weight of } \\
\text { whole plant }\end{array}$} & \multirow[b]{2}{*}{$\begin{array}{l}\text { Plant } \\
\text { height }\end{array}$} & \multirow[b]{2}{*}{$\begin{array}{c}\text { Stem } \\
\text { diameter }\end{array}$} & \multirow[b]{2}{*}{$\begin{array}{l}\text { Root-shoot } \\
\text { ratio }\end{array}$} & \multirow[b]{2}{*}{$\begin{array}{c}\text { Strong } \\
\text { seedling index }\end{array}$} \\
\hline & $\begin{array}{c}\text { Dry } \\
\text { weight }\end{array}$ & $\begin{array}{c}\text { Fresh } \\
\text { weight }\end{array}$ & $\begin{array}{c}\text { Dry } \\
\text { weight }\end{array}$ & $\begin{array}{c}\text { Fresh } \\
\text { weight }\end{array}$ & & & & & \\
\hline & & 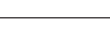 & g & 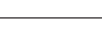 & 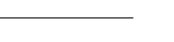 & $\mathrm{cm}$ & $\mathrm{mm}$ & & \\
\hline $\mathrm{R}$ & $9.211 \mathrm{e}$ & $80.232 \mathrm{c}$ & $0.242 \mathrm{e}$ & $3.011 \mathrm{e}$ & $9.453 \mathrm{e}$ & $47.47 \mathrm{a}$ & $7.12 \mathrm{c}$ & $0.026 \mathrm{~d}$ & $1.418 \mathrm{e}$ \\
\hline $\mathrm{R} / \mathrm{R}$ & $6.783 \mathrm{f}$ & $54.053 \mathrm{f}$ & $0.122 \mathrm{f}$ & $2.306 f$ & $6.905 f$ & $40.63 b$ & $7.23 \mathrm{c}$ & $0.018 \mathrm{e}$ & $1.229 \mathrm{f}$ \\
\hline R/GAN & $15.014 \mathrm{~b}$ & $99.577 \mathrm{a}$ & $0.383 \mathrm{c}$ & $3.241 \mathrm{~d}$ & $15.397 b$ & $35.87 \mathrm{~d}$ & $8.58 \mathrm{a}$ & $0.026 \mathrm{~d}$ & $3.683 \mathrm{a}$ \\
\hline $\mathrm{R} / \mathrm{ZA}$ & $15.361 \mathrm{a}$ & $91.198 \mathrm{~b}$ & $0.524 \mathrm{a}$ & $9.112 \mathrm{a}$ & $15.885 \mathrm{a}$ & $39.47 \mathrm{c}$ & $8.10 \mathrm{~b}$ & $0.034 \mathrm{c}$ & $3.260 \mathrm{~b}$ \\
\hline R/GUO & $9.850 \mathrm{~d}$ & $60.863 \mathrm{e}$ & $0.355 d$ & $3.677 \mathrm{c}$ & $10.205 d$ & $35.00 \mathrm{e}$ & $8.10 \mathrm{~b}$ & $0.036 \mathrm{~b}$ & $2.363 d$ \\
\hline R/GX & $11.635 \mathrm{c}$ & $73.342 \mathrm{~d}$ & $0.452 b$ & $4.315 b$ & $12.087 \mathrm{c}$ & $31.53 \mathrm{f}$ & $8.21 \mathrm{~b}$ & $0.039 \mathrm{a}$ & $3.148 \mathrm{c}$ \\
\hline
\end{tabular}

Means followed by the same letter in the columns do not differ significantly according to Tukey' $\mathrm{s}$ test $(\mathrm{p} \leq 0.05)$. Data are means of $\mathrm{n}=3$. R: 'Ruifen 882 '; R/R: 'Ruifen 882 '/'Ruifen 882'; R/GAN: 'Ruifen 882 '/'Ganzhen 1'; R/ZA: 'Ruifen 882'/'Zhenai 1'; R/GUO: 'Ruifen 882'/‘Guozhen 1'; R/GUANG: 'Ruifen 882'/‘Guangzhen 1'. 
Figure 1. Chlorophyll contents under different graft combinations.

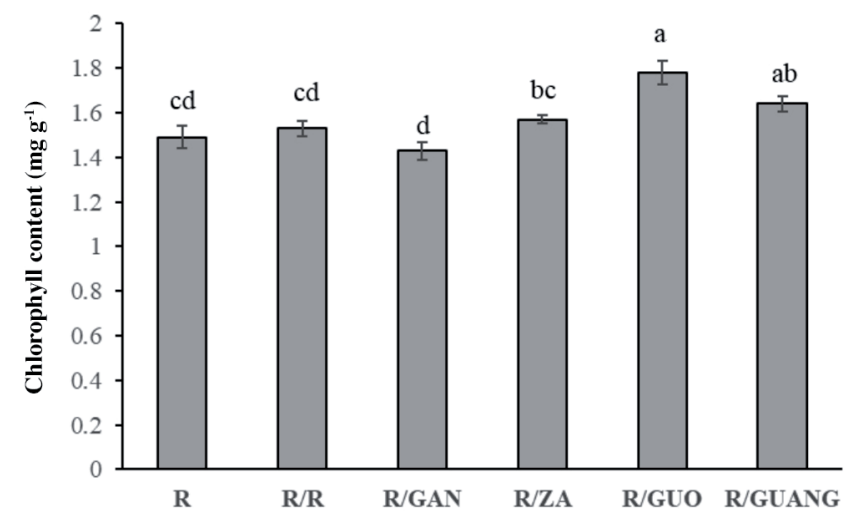

R: 'Ruifen 882'; R/R: 'Ruifen 882'/'Ruifen 882'; R/GAN: 'Ruifen 882'/“Ganzhen 1'; R/ZA: 'Ruifen 882'/'Zhenai 1'; R/GUO: 'Ruifen 882 /'GGuozhen 1'; R/GUANG: 'Ruifen 882 '/‘Guangzhen 1'

Table 5. Contents of mineral nutrients in seedlings of different tomato graft combinations.

\begin{tabular}{lccccccccc}
\hline Scion/Rootstock & $\mathrm{P}$ & $\mathrm{K}$ & $\mathrm{Ca}$ & $\mathrm{Mg}$ & $\mathrm{Fe}$ & $\mathrm{Zn}$ & $\mathrm{Na}$ & $\mathrm{Mn}$ & $\mathrm{Cu}$ \\
\hline & \multicolumn{7}{c}{} & \multicolumn{7}{c}{$\mathrm{mg} \mathrm{kg}^{-1}$} & & & & \\
$\mathrm{nyyyyyyyyy}$ & $291.21 \mathrm{a}$ & $1263.62 \mathrm{e}$ & $601.36 \mathrm{a}$ & $291.52 \mathrm{a}$ & $10.39 \mathrm{a}$ & $1.71 \mathrm{~b}$ & $158.07 \mathrm{a}$ & $1.90 \mathrm{a}$ & $0.78 \mathrm{a}$ \\
$\mathrm{R} / \mathrm{R}$ & $263.58 \mathrm{~b}$ & $1296.21 \mathrm{~d}$ & $580.10 \mathrm{c}$ & $271.38 \mathrm{~b}$ & $6.52 \mathrm{~b}$ & $1.18 \mathrm{c}$ & $119.27 \mathrm{c}$ & $0.32 \mathrm{~b}$ & $0.41 \mathrm{~cd}$ \\
R/GAN & $209.52 \mathrm{~d}$ & $1328.58 \mathrm{c}$ & $481.53 \mathrm{~d}$ & $238.15 \mathrm{~d}$ & $7.16 \mathrm{~b}$ & $1.07 \mathrm{c}$ & $96.32 \mathrm{~d}$ & $0.45 \mathrm{bd}$ & $0.25 \mathrm{e}$ \\
R/ZA & $253.13 \mathrm{c}$ & $1512.65 \mathrm{~b}$ & $396.20 \mathrm{e}$ & $217.30 \mathrm{e}$ & $6.60 \mathrm{~b}$ & $2.73 \mathrm{a}$ & $134.68 \mathrm{~b}$ & $0.73 \mathrm{~cd}$ & $0.36 \mathrm{~d}$ \\
R/GUO & $252.64 \mathrm{c}$ & $1605.10 \mathrm{a}$ & $594.90 \mathrm{~b}$ & $260.40 \mathrm{c}$ & $9.79 \mathrm{a}$ & $1.55 \mathrm{bc}$ & $155.71 \mathrm{a}$ & $0.89 \mathrm{c}$ & $0.69 \mathrm{~b}$ \\
R/GUANG & $261.46 \mathrm{~b}$ & $1113.25 \mathrm{f}$ & $483.24 \mathrm{~d}$ & $215.83 \mathrm{e}$ & $4.04 \mathrm{c}$ & $2.53 \mathrm{a}$ & $83.58 \mathrm{e}$ & $0.64 \mathrm{bcd}$ & $0.49 \mathrm{c}$
\end{tabular}

Different letters within the same column and data of sampling show significant differences according to Tukey's HSD test $(\mathrm{P} \leq 0.05)$. Data are means of $\mathrm{n}=3$.

R: 'Ruifen 882'; R/R: 'Ruifen 882'/'Ruifen 882'; R/GAN: 'Ruifen 882'/‘Ganzhen 1'; R/ZA: 'Ruifen 882'/'Zhenai 1'; R/GUO: 'Ruifen 882 '/‘Guozhen 1'; R/GUANG: 'Ruifen 882 '/‘Guangzhen 1'.

Table 6. Fruit yield under different tomato graft combinations.

\begin{tabular}{|c|c|c|c|c|c|}
\hline Scion/Rootstock & Initial stage & Middle stage & Later stage & Total yield & Weigh \\
\hline & & 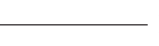 & & & $\mathrm{g}_{\text {fruit }^{-1}}$ \\
\hline $\mathrm{R}$ & $16.35 \mathrm{~b}$ & $15.07 \mathrm{e}$ & $5.26 \mathrm{~d}$ & $36.68 \mathrm{e}$ & $0.27 \mathrm{a}$ \\
\hline $\mathrm{R} / \mathrm{R}$ & $9.35 \mathrm{e}$ & $24.36 \mathrm{a}$ & $4.46 \mathrm{e}$ & $38.17 d$ & $0.29 \mathrm{a}$ \\
\hline $\mathrm{R} / \mathrm{GAN}$ & $18.65 \mathrm{a}$ & $19.69 \mathrm{c}$ & $6.67 \mathrm{ab}$ & $45.01 \mathrm{a}$ & $0.27 \mathrm{a}$ \\
\hline R/GUO & $16.12 \mathrm{c}$ & $20.76 b$ & $5.98 \mathrm{de}$ & $42.86 \mathrm{~b}$ & $0.28 \mathrm{a}$ \\
\hline $\mathrm{R} / \mathrm{ZA}$ & $13.85 \mathrm{~d}$ & $17.21 \mathrm{~d}$ & $6.17 b c$ & $37.23 \mathrm{e}$ & $0.29 \mathrm{a}$ \\
\hline R/GUANG & $13.90 \mathrm{~d}$ & $20.43 b$ & $7.37 \mathrm{a}$ & $41.70 \mathrm{c}$ & $0.25 \mathrm{~d}$ \\
\hline
\end{tabular}

Different letters within the same column and data of sampling show significant differences according to Tukey's HSD test $(\mathrm{P} \leq 0.05)$. Data are means of $\mathrm{n}=3$.

R: 'Ruifen 882'; R/R: 'Ruifen 882'/'Ruifen 882'; R/GAN: 'Ruifen 882'/“Ganzhen 1'; R/ZA: 'Ruifen 882'/'Zhenai 1'; R/GUO: 'Ruifen 882'/“Guozhen 1'; R/GUANG: 'Ruifen 882'/‘Guangzhen 1'.

\section{Yield and quality assessment}

Grafting can improve fruit quality and increase yield (Schwarz et al., 2013). Four graft combinations resulted in higher total yield than the non-grafted and self-grafted combinations in this study (Table 6). Among the four grafting combinations, R/GAN and R/GUO had better performance than R/ZA and R/GUANG. However, the weight per fruit was nonsignificantly different.

The data in Table 7 show that the six combinations had nonsignificant difference in fruit hardness, soluble sugar, sugar acid ratio and lycopene and a small difference in soluble solids. R/ZA had higher soluble solid levels than the other three graft combinations. However, there was a significant difference in fruit vitamin $\mathrm{C}$ contents under the different combinations, and R/GUANG had the highest vitamin $\mathrm{C}$ among the four graft combinations. These fruit quality parameters results indicated that grafting did not influence the quality of tomato fruits. 
Table 7. Comparison of fruit quality under different graft combinations.

\begin{tabular}{|c|c|c|c|c|c|c|}
\hline Scion/Rootstock & $\begin{array}{c}\text { Fruit } \\
\text { hardness }\end{array}$ & $\begin{array}{l}\text { Soluble } \\
\text { solids }\end{array}$ & $\begin{array}{l}\text { Soluble } \\
\text { sugar }\end{array}$ & $\begin{array}{l}\text { Sugar } \\
\text { acid ratio }\end{array}$ & Vitamin C & Lycopene \\
\hline & & $\%$ & $\mathrm{mg} \mathrm{g}^{-1}$ & & $\mathrm{mg} 100 \mathrm{~g}^{-1}$ & $\mathrm{mg} 100 \mathrm{~g}^{-1}$ \\
\hline $\mathrm{R}$ & 7.42ab & $5.12 \mathrm{a}$ & $4.20 \mathrm{a}$ & $111.16 \mathrm{a}$ & $10.95 \mathrm{a}$ & $6.18 \mathrm{a}$ \\
\hline $\mathrm{R} / \mathrm{R}$ & $6.87 \mathrm{ab}$ & $4.50 \mathrm{ab}$ & $4.13 \mathrm{a}$ & $133.85 \mathrm{a}$ & $9.26 \mathrm{~b}$ & $6.04 \mathrm{a}$ \\
\hline R/GAN & $7.68 \mathrm{a}$ & $3.72 b$ & $3.81 \mathrm{a}$ & $95.69 a$ & $5.28 \mathrm{e}$ & $6.31 \mathrm{a}$ \\
\hline $\mathrm{R} / \mathrm{ZA}$ & $7.47 \mathrm{ab}$ & $4.67 \mathrm{a}$ & $3.92 \mathrm{a}$ & $105.17 \mathrm{a}$ & $6.61 d$ & $5.28 \mathrm{a}$ \\
\hline R/GUO & $7.45 \mathrm{ab}$ & $4.25 \mathrm{ab}$ & $3.52 \mathrm{a}$ & $139.20 \mathrm{a}$ & $4.97 \mathrm{e}$ & $6.92 \mathrm{a}$ \\
\hline R/GUANG & $6.53 b$ & $4.30 \mathrm{ab}$ & $4.10 \mathrm{a}$ & $119.40 \mathrm{a}$ & $8.23 \mathrm{c}$ & $7.30 \mathrm{a}$ \\
\hline
\end{tabular}

Different letters within the same column and data of sampling show significant differences according to Tukey's HSD test (P $\leq 0.05)$. Data are means of $\mathrm{n}=3$.

R: 'Ruifen 882'; R/R: 'Ruifen 882\%/'Ruifen 882'; R/GAN: 'Ruifen 882'/'Ganzhen 1'; R/ZA: 'Ruifen 882'/'Zhenai 1'; R/GUO: 'Ruifen 882 '/'Guozhen 1'; R/GUANG: 'Ruifen 882 '/‘Guangzhen 1'.

\section{DISCUSSION}

In recent years, coconut coir has been widely used in crop production, especially in greenhouse cultivation. Because of their excellent physical properties and biological features, coconut coirs can significantly improve plant growth and development (Oliveira et al., 2009; Xiong et al., 2017; Mariotti et al., 2020) and are economical and environmentally friendly (Berruti and Scariot, 2012). Grafting is currently regarded as a rapid tool aimed at increasing the environmental stress tolerance of vegetables (Fallik and Ilic, 2014). Grafting can overcome the obstacles of continuous cropping, increase crop yield, and improve fruit quality (Savvas et al., 2012; Fallik and Ilic, 2014). Grafting can also reduce infections by soilborne pathogens as well as enhance tolerance against abiotic stresses (Lee et al., 2010; Schwarz et al., 2013). Rootstocks are the main factors that influence graft performance. Selecting suitable rootstocks is important for crop production.

The casing grafting method was used in this study, and successful graft combinations of the commercial scion 'RuiFen 882 ' with four tomato rootstocks were obtained. Each combination showed a good affinity with a graft survival rate of more than $90 \%$, especially R/GUO, which showed a rate up to $97.93 \%$. Genetic factors, humidity, seedling size, grafting method and so on can all contribute to the graft survival rate, and better graft performance can be obtained with the same species, higher humidity, suitable seedling size and grafting method (Aslam et al., 2020).

A positive effect of grafting on the growth and development of seedlings has previously been reported (Savvas et al., 2012; Fu et al., 2018; Fullana-Pericas et al., 2018). Grafting improved the growth and development of tomato plants at the seedling stage in this study, and the R/ZA graft combination had better results in terms of plant height, stem diameter, and the fresh and dry weights of aboveground and under-ground part than other combinations and non-grafted and selfgrafted controls. However, the dry and fresh weights of above-ground and under-ground part, plant height, dry weight of the whole plant and seedling index of $\mathrm{R} / \mathrm{R}$ were all lower than those of $\mathrm{R}$, which can be due to wound healing and delayed growth in the early harvest stage.

The root system and above-ground part of plant interact with each other. The growth and vitality of roots affect plant growth and development and yield and quality, while a large amount of energy obtained by photosynthesis of the aboveground part supplied to roots. Studies have concluded that grafting can increase chlorophyll content and leaf area of plants, thereby increasing plant photosynthesis (Khah, 2011; Haberal et al., 2016). The developed roots have a larger rootshoot ratio and a stronger ability to absorb nutrients, thereby increasing the photosynthesis rate and chlorophyll content (Martínez-Ruiz et al., 2019). In this experiment, several graft combinations increased the chlorophyll content and the absorption of mineral elements of tomato. Compared to the control R and R/R, the graft combinations of R/ZA, R/GUO and R/GUANG increased the chlorophyll content. R/GUO had the highest absorption of mineral elements among the combinations. Obviously, different graft combinations had different effects on the chlorophyll content and the absorption of mineral nutrients.

Reports on the effects of grafting on tomato quality have been both positive and negative (Flores et al., 2010; Rouphael et al., 2010; Fullana-Pericas et al., 2018). It has been reported that there were nonsignificant differences among the four treatments in terms of $\mathrm{pH}$ and fruit $\mathrm{Cu}, \mathrm{Mn}, \mathrm{Ca}, \mathrm{Zn}, \mathrm{Fe}$ contents (Khah, 2011). Eggplants grafted onto two tomato rootstocks gave higher yields and larger fruits than non-grafted plants, but there were nonsignificant differences in the 
mineral compositions of fruits from non-grafted plants (Passam et al., 2005). The results of this experiment indicated that four graft combinations all increased the fruit yield, but different rootstocks had nonsignificant effect on most tomato fruit quality parameters except vitamin $\mathrm{C}$ content.

It is worth mentioning that most graft combinations had lower yields in the initial stage of harvest than the non-grafted control. The most likely reason was that the grafting wound needed time to heal and the initial flowering time was delayed. However, the fruit yield increased rapidly with plant growth, and the effects of rootstocks emerged.

\section{CONCLUSIONS}

This experiment measured tomato survival rate, growth index, initial stage yield and fruit quality for rootstock screening. Based on the analysis of various traits, the rootstock 'Guozhen 1' was excellent in terms of plant growth, development, quality and yield. 'Guozhen 1' is suitable for demonstration and extension activities as a rootstock for grafting under coconut coir cultivation in the greenhouse. Of course, comprehensive analysis of various factors in research and the formulation and optimization of production methods, can achieve high-quality and high-yield purposes more effectively.

\section{ACKNOWLEDGEMENTS}

This work was supported by the Modern Agricultural Industry Technology System of Beijing Innovation Team Project (BAIC01-2020) and the Construction of Beijing Science and Technology Innovation and Service Capacity in Top Subjects (CEFF-PXM2019_014207_000032).

\section{REFERENCES}

Aloni, B., Cohen, R., Karni, L., Aktas, H., and Edelstein, M. 2010. Hormonal signaling in rootstock-scion interactions. Scientia Horticulturae 127(2):119-126. doi:10.1016/j.scienta.2010.09.003.

Andrjushchenko, V.K., Butkevich, S.T., and Zatuliveter, V.F. 1978. Express method of ascorbic-acid content determination in tomato fruit. Fiziologiya I Biokhimiya Kulturnykh Rastenii 10(6):648-650.

Aslam, W., Noor, R.S., Hussain, F., Ameen, M., Ullah, S., and Chen, H. 2020. Evaluating morphological growth, yield, and postharvest fruit quality of cucumber (Cucumis sativus L.) grafted on cucurbitaceous rootstocks. Agriculture 10(4):101. doi:10.3390/agriculture10040101.

Auerswald,H., Drews, M., and Krumbein, A. 1996. The effect of different methods of cultivation on characteristics of the internal quality of greenhouse tomatoes in the course of one year. Gartenbauwissenschaft 61(2):77-83. doi:10.1002/ijc.2910150506.

Berruti, A., and Scariot, V. 2012. Coconut fiber: A peat-like substrate for acidophilic plant cultivation. Acta Horticulturae 952:629-635. doi:10.17660/ActaHortic.2012.952.79.

Ceballos, R., and Rioja, T. 2019. Rootstock affects the blend of biogenic volatile organic compounds emitted by 'Hass' avocado. Chilean Journal of Agricultural Research 79:330-334. doi:10.4067/S0718-58392019000200330.

Chang, T., Liu, X., Xu, Z., and Yang, Y. 2010. Effects of light spectral energy distribution on growth and development of tomato seedlings. Scientia Agricultura Sinica 43(8):1748-1756. doi:10.4028/www.scientific.net/AMM.37-38.1549.

Fallik, E., and Ilic, Z. 2014. Grafted vegetables-the influence of rootstock and scion on postharvest quality. Folia Horticulturae 26(2):79-90. doi:10.2478/fhort-2014-0008.

Flores, F.B., Sanchez-Be1, P., Estañ, M.T., Martinez Rodriguez, M.M., Moyano, E., Morales, B., et al. 2010. The effectiveness of grafting to improve tomato fruit quality. Scientia Horticulturae 125(3):211-217. doi:https://doi.org/10.1016/j.scienta.2010.03.026.

Fu, Q.S., Zhang, X.Y., Kong, Q.S., Bie, Z.L., and Wang, H.S. 2018. Grafting onto pumpkin rootstock is an efficient alternative to improve melon tolerance to nacl stress. European Journal of Horticultural Science 83(6):337-344. doi:10.17660/eJHS.2018/83.6.1.

Fullana-Pericas, M., Ponce, J., Conesa, M.A., Juan, A., Ribas Carbo, M., and Galmes, J. 2018. Changes in yield, growth and photosynthesis in a drought-adapted Mediterranean tomato landrace (Solanum lycopersicum 'Ramellet') when grafted onto commercial rootstocks and Solanum pimpinellifolium. Scientia Horticulturae 233:70-77. doi:10.1016/j.scienta.2018.01.045.

Haberal, M., Korpe, D.A., Iseri, O.D., and Sahin, F.I. 2016. Grafting tomato onto tobacco rootstocks is a practical and feasible application for higher growth and leafing in different tobacco-tomato unions. Biological Agriculture and Horticulture 32(4):248-257. doi:10.1080/01448765.2016.1169218. 
Hernández-Leal, E., Lobato-Ortiz, R., García-Zavala, J., Hernández-Bautista, A., Reyes-López, D., and Bonilla-Barrientos, O. 2019. Stability and breeding potential of commercial tomato hybrids. Chilean Journal of Agricultural Research 79:181-189. doi:10.4067/S0718-58392019000200181.

Khah, E.M. 2011. Effect of grafting on growth, performance and yield of aubergine (Solanum melongena L.) in greenhouse and open-field. International Journal of Plant Production 5(4):359-366. doi:10.1007/s12230-011-9209-0.

Krumbein, A., Peters, P., and Brückner, B. 2004. Flavour compounds and a quantitative descriptive analysis of tomatoes (Lycopersicon esculentum Mill.) of different cultivars in short-term storage. Postharvest Biology and Technology 32(1):1528. doi:10.1016/j.postharvbio.2003.10.004.

Krumbein, A., Schwarz, D., and Klaering, H.P. 2006. Effects of environmental factors on carotenoid content in tomato (Lycopersicon esculentum (L.) Mill.) grown in a greenhouse. Journal of Applied Botany and Food Quality 80(2):160-164. doi:http://hdl.handle.net/2078.1/151622.

Lee, J.M., Kubota, C., Tsao, S.J., Bie, Z., Echevarria, P.H., Morra, L., et al. 2010. Current status of vegetable grafting: Diffusion, grafting techniques, automation. Scientia Horticulturae 127(2):93-105. doi:10.1016/j.scienta.2010.08.003.

Martínez-Ruiz, A., López-Cruz, I.L., Ruiz-García, A., Pineda-Pineda, J., and Prado-Hernández, J.V. 2019. Hortsyst: A dynamic model to predict growth, nitrogen uptake, and transpiration of greenhouse tomatoes. Chilean Journal of Agricultural Research 79:89-102. doi:10.4067/S0718-58392019000100089.

Mariotti, B., Martini, S., Raddi, S., Tani, A., Jacobs, D.F., Oliet, J.A., et al. 2020. Coconut coir as a sustainable nursery growing media for seedling production of the ecologically diverse Quercus species. Forests 11(5):522. doi:10.3390/f11050522.

Mauromicale, G., Longo, A.M.G., and Monaco, A.L. 2011. The effect of organic supplementation of solarized soil on the quality of tomato fruit. Scientia Horticulturae 129(2):189-196. doi:10.1016/j.scienta.2011.03.024.

Nguyen, V.H., and Yen, C.R. 2018. Rootstock age and grafting season affect graft success and plant growth of papaya (Carica papaya L.) in greenhouse. Chilean Journal of Agricultural Research 78:59-67. doi:10.4067/S0718-58392018000100059.

Oliveira, A.B., Hernandez, F.F.F., e de Assis, R.N. 2009. Absorção de nutrientes em mudas de berinjela cultivadas em pó de coco verde. Revista Caatinga 22(2):139-143. doi:10.1007/978-1-4020-8804-9_25.

Passam, H.C., Stylianou, M., and Kotsiras, A. 2005. Performance of eggplant grafted on tomato and eggplant rootstocks. European Journal of Horticultural Science 70(3):130-134

Rouphael, Y., Schwarz, D., Krumbein, A., and Colla, G. 2010. Impact of grafting on product quality of fruit vegetables. Scientia Horticulturae 127(2):172-179. doi:10.1016/j.scienta.2010.09.001.

Savvas, D., Ntatsi, G., Moiras, N., Tsakalidis, A., Ropokis, A., and Liopa-Tsakalidi, A. 2012. Impact of grafting and rootstock on the responses of cucumber to heavy metal stress. Acta Horticulturae 960:49-56. doi:10.17660/ActaHortic.2012.960.5.

Schwarz, D., Oztekin, G.B., Tuzel, Y., Bruckner, B., and Krumbein, A. 2013. Rootstocks can enhance tomato growth and quality characteristics at low potassium supply. Scientia Horticulturae 149:70-79. doi:10.1016/j.scienta.2012.06.013.

Wang, L., Luan, B., Liu, X., Wang, P., and Wang, Y. 2017. Relationship between the contents of nutrients and chlorophylls in leaves of different grape varieties and their resistance to Apolygus lucorum (Hemiptera: Miridae). Acta Entomologica Sinica 60(5):570-575. doi:10.16380/j.kcxb.2017.05.009.

Wang, G., Qu, P., Huang, H., Wu, G., and Yan, H. 2020. Evaluation of coconut coir dust/modified urea-formaldehyde resins as a growing medium for pepper seedlings. HortTechnology 30(3):322-330. doi:10.21273/horttech04542-19.

Xiong, J., Tian, Y.Q., Wang, J.G., Liu, W., and Chen, Q. 2017. Comparison of coconut coir, rockwool, and peat cultivations for tomato production: Nutrient balance, plant growth and fruit quality. Frontiers in Plant Science 8:1327. doi:10.3389/fpls.2017.01327

Zhao, H., Wu, Y., Li, T., Yan, Z., Zhu, Q., Shan, Y., et al. 2018. Effects of adding nitrogen to vermicompost on tomato seedlings under greenhouse conditions. Communications in Soil Science and Plant Analysis 49(3):303318. doi:10.1080/00103624.2018.1427256. 